\title{
Banco Nacional da Previdência Social (*)
}

\author{
OsCAR Vitorino Moreira
}

\section{Objetivo e Plano do trabalho}

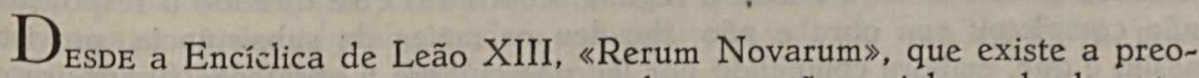
cupação geral de ser estudada e equacionada a questão social, sendo de notar os estudos feitos em diversos países. Infelizmente não tem predominado um espirito humano, econômico e cristão nesses estudos, prevalecendo o sentido político. Poucos são os exemplos de estudos visando aturadamente aquêles aspetos; muitos vestem as roupagens caracterizantes daquelas condiçóes mas, em realidade, visam exclusivamente o lado político.

A questão social é essencialmente de fundo humano e econômico, devendo ser tratada por um espirito cristão. Já houve tempo em que era dito que essa questão nada mais seria que um caso de polícia. Como poderia ser um caso de policia, em seu todo, se observamos que ela resulta de fatôres independentes do indivíduo? A sêca do Nordeste, a geada, a superprodução, a recessão, a superpopulação, a escassez de alimentos, e tantas outras causas poderão ser desconhecidas para classificarmos a questão social como um caso de polícia? Aquelas causas, aliadas a diversas outras, são as determinantes da chamada questão social.

O Brasil, a partir de 1930 , procurou equacionar o problema e o enfrentrou, pois não poderia progredir sem dar condiçốes de tranqüilidade a seu povo e principalmente à grande parcela que mais sente os efeitos das deficiências econômicas. Inegàvelmente foram dados passos agigantados no sentido da solução do problema e muito tem sido alardeado a êsse respeito. A certeza das medidas só o tempo dirá. Vivemos a época e ainda é cedo para concluirmos; será necessária distância para o julgamento. Embora não possamos conscientemente afirmar os bons resultados, pelo menos será possivel provarmos que temos o desejo de encontrar uma solução. É merecedor de elogio aquêle que, ao menos, tenta encontrar a solução, em vêz de cruzar os braços.

Na solução do problema nacional, evidentemente um dos mais importantes, já que diz respeito a enorme parcela do povo, a previdência social sobressai naturalmente. A instituição do seguro, como meio hábil de amparo na velhice, na enfermidade, e noutras formas que ali se enquadram, é reconhecida com uma das soluções convenientes. Não se trata da única, mas de uma

(*) Monografia com Mençăo Honrosa. 
delas. O ideal seria o indivíduo conseguir os meios para não carecer do amparo externo, que não houvessem fatôres independentes de sua vontade para o prejudicar, mas isso não passa de quimera e nosso trabalho não ingressará no campo da utopia onde o devaneio representa os vôos do espírito e serve à demagogia, às finalidades políticas, a que somos infensos. De que vale pairar nas alturas, voar alto, sentir a vastidão do espaço se é na terra, no chão, que existem os problemas, que o povo vive, que os elementos para as soluções só aí são encontrados? Valeria lembrar o velho ditado sueco «por mais alto que o pássaro voe, terá de baixar à terra para beber água»!

A providência social foi instituida no Brasil em forma ampla a partir de 1930, pois não podemos ver em ninúsculas instituições antigas, como montepios, caixas, mútuas e outras formas, um regime securitário como o atual. Embora o Estado haja criado o regime securitário e se tornado o responsável, não completou sua obra e não lhe deu os meios de subsistência previstos; assim é que, embora compelido por lei, não cumpre a obrigação financeira que tem para com as instituições previdenciárias. O certo, o inevitável é que, daqui há algum tempo, os cofres públicos terão de fornecer diàriamente os quantitativos para atender às responsabilidades assumidas pelas instituições, pois elas não mais terão recursos para tanto. Se analisássemos a atual situação, iriamos concluir da mesma forma por que diversos estudiosos já têm feito e diríamos que o regime previdenciário se encontra tècnicamente falido. Os motivos são, em primeiro lugar o não cumprimento, por parte do Estado, com sua obrigação financeira, isto é, concorrer com a têrça parte para a formação dos recursos das instituições, já que o regime é de triplice contribuição. Lembremô-nos de que a obrigação estatal decorre do mandamento constitucional, o que é mais grave. Vejamos o que se contém na atual Constituição.

«Art. 157. A legislação do trabalho e a da previdência social obedecerão aos seguintes preceitos, além de outros que visem à melhoria das condições dos trabalhadores:

XVI - previdência, mediante contribuição da União, do empregador e do empregado, em favor da maternidade e contra as conseqüência da velhice, da invalidez e da morte."

A contribuição estatal é obrigatória e nos cálculos atuariais para a instituição do seguro social, isto é, da previdência social, foi aquela computada. Assim, sem qualquer outro exame, podemos concluir que, não ingressando a parte do Estado, o regime instituído não poderá ter êxito, falirá inexoràvelmente. Por outro lado, tratando-se de instituições de previdência, de formas securatórias em bases atuariais, para seu êxito, têm estas de ser obedecidas rigorosamente. Isto é comesinho, mas temos de nos referir a êste ponto pelo seguinte: - A despeito das bases de cálculo, as instituições de previdência, não raro, por fôrça de legislação posterior, são obrigadas a pagar aposentadorias e pensões em bases superiores àquelas para as quais foram recebidas as contribuições! Não será preciso percorrermos tôdas as instituições para verificarmos que um indivíduo terá contribuido, durante todo tempo em que era associado da instituição, digamos, com $\mathrm{Cr} \$ 4.000,00$ e, aposentado, falecendo tempos depois, ainda deixou pensão para os herdeiros legais, somando até agora o dispêndio da instituição em mais de $\operatorname{Cr} \$ 300.000,00$ ! Haverá insti- 
tuição que suporte tal procedimento? Pagar 75 vêzes o que rccébeu? Podem haver razões humanas, razões do coração que indiquem uma melhoria das aposentadorias e das pensões, não contestamos, mas ao apreciarmos o fato do ponto de vista econômico ou atuarial, verificamos a trital impossibilidade do atendimento daquelas razões, por mais ponderávcis que sejam. As leis que isso determinam não se fundam em motivos de ordem econômica, não atentam para a conseqüência inevitável que é a falência irremediável de uma instituição necessária; a finalidade de tais leis é evidentemente política. Infelizmente estamos vivendo um momento em que o homem é um desavisado e não se sente responsabilizado pelo que ocorrer no futuro. O politico de hoje é um homem que só vê o dia que vivemos, o seu interêsse; não pratica atos que convenham ao futuro e possam impopularizá-lo. Que carga pesada irão receber nossos filhos e nossos netos! Chegamos a ter a impressão de que o homem da atualidade está crente de que uma hecatombe fará sucumbir a espécie humana ou um engenho nuclear extinguirá a vida na face da Terra, pois êle não se preocupa com o dia de amanhã.

Não comungamos com tais pensamentos e por isso apresentamos um trabalho que visa minorar os efeitos dos males que vêm sendo praticados desatinadamente.

A criação do Banco Nacional da Previdência Social é, por nós, considerada como um meio de diminuir os males do regime em que vivem as instituições previdenciárias. Não pensamos, por êsse meio, salvá-las, mas reduzir o vulto dos fatôres negativos.

Nosso trabalho não pode ser de maior profundidade, não que fôsse êsse nosso intuito, mas em razão do que dispõe o $\mathrm{n}^{\circ} \mathrm{I}$, item 3 das Instruções reguladoras do Concurso que limitam ao máximo de 30 (trinta) páginas a monografia. Teremos de aceitar a limitação do número de páginas como uma homenagem à inteligência, ao espirito de sintese e de concisão do autor, pois as Instruções ao determinarem tal limite, tiveram o condão de pressupor que só participariam do Concurso aquêles que tratassec dos "assuntos de administração federal de interêsse nacional" apresentando "trabalhos técnicos-administrativos" sintéticos e valiosos. Assim, aproveitamos o ensejo para agradecer o elogio, talvez involuntário, que se contém nas «Instruções» e justificamos o limite de nosso trabalho. Compreenderá o leitor os motivos por que não podemos efetuar uma análise profunda do problema, mas devemos, ainda, reconhecer que na era dinâmica que vivemos, quando não há tempo para leituras, mister se faz que evitemos os prolixos...

\section{Plano}

O plano dêste trabalho se resume em mostrar a situação atual do aspeto financeiro das instituições previdenciárias, assim como ligeiramente o que tange ao lado econômico e, em seguida, a sugerir a criação do Banco que deverá dar solidez à economia do regime previdenciário, embora não the seja possível salvar infalivelmente da verdadeira ruina em que as instituições se encontram já que os fatôres determinantes ainda não foram removidos. $O$ Banco é necessário agora como o será no futuro, mesmo que removidos os atuais fatôres negativos, como teremos ocasião de verificar. 
Êste é um trabalho simples, um estudo que mais se preocupa em alertar, em apontar uma solução, do que em se qualificar como um marco, um ponto de partida para a solução ou salvação final de um regime.

\section{DesenVolvimento}

Feita esta apresentação, passaremos à verdadeira finalidade dêste trabalho, ou seja, a propositura da criação do Banco Nacional da Previdência Social. Desejamos lembrar, de início, que o nome dado ao estabelecimento não se restringe, não limita a uma finalidade. É comum sabermos através do rótulo o que se contém no bôjo, mas achamos que devemos conhecer o conteúdo sem nos iludirmos com o continente. Para os que se deixam levar pelo rótulo, sem analisarem o conteúdo, poderíamos perguntar se - parati em garrafa de «champagne» é êsse vinho espumante? Esta observação sôbre o nome que dainos ao banco provém do fato de que seu nome deveria ser Banco Nacional do Trabalho, mas sentimos que isso iria ser aberrante e inconveniente, como, também, suscitaria críticas, dentre as quais a de que, amanhã, seria proposta a criação dos bancos da educação (seriam os escolares...). da justiça (com nossos perdões...), da viação, etc. . Assim, atribuimos o nome que melhor nos pareceu atender às finalidades que temos em vista.

Para justificarmos a necessidade de uma instituição bancária, entedemos conveniente revelar o vulto financeiro e por isso, começaremos mostrando a quanto atingem os orçamentos da receita das instituições de previdência e outros do âmbito.

De acôrdo com os orçamentos aprovados pelo Departamento Nacionas da Previdência Social, são as seguintes as receitas previstas para o ano de 1959, das instituições abaixo:

$\operatorname{Cr} \$ \quad \operatorname{Cr} \$$

I. A. P. B. $\ldots \ldots \ldots \ldots$. $3.687 .350 .345,20$

I. A. P. C. $\ldots \ldots \ldots \ldots \ldots$ 13.602.350.170,00

I. A. P. I. $\ldots \ldots \ldots \ldots \ldots$ 28. $2861.618 .430,90$

I. A. P. M. ........ $2.050 .553 .800,00$

I. A. P. E. T. C. ..... $6.841 .621 .562,00$

C. A. P. F. E. S. P. ... $8.148 .272 .000,00$

S. A. M. D. U. ...... $854.459 .440,00$

S. A. P. S. ......... $3.345 .750 .950,00$

Total

$67.391 .976 .698,10$

A fim de darmos uma idéia do comportamento orçamentário, da sua evolução e outros fatos, apresentamos uma comparação entre a despesa prevista para 1958 e a efetuada realmente, assim como a percentagens desta última sôbre aquela, o que nos orienta para melhor fazermos idéia sôbre o ano em 
curso, com base nas receitas previstas, sabendo-se que nos orçamentes das entidades as receitas $e$ as despesas são apresentadas em forma equilibrada.

Entidade

I. A. P. B

I. A. P. C.

I. A. P. I.

I. A. P. M.

I. A. P. E. T. C. $\ldots \ldots$.

C. A. P. F. E. S. P. . . .

S. A. M. D. U. $\ldots \ldots \ldots$.

S. A. P. S. $\ldots \ldots \ldots \ldots \ldots$

Total
Despesa prevista

Cr\$

$1.394 .447 .432,80$

$6.835 .616 .000,00$

$16.314 .046 .121,80$

$1.620 .442 .476,00$

$5.658 .090 .954,00$

$5.000 .235 .200,00$

$797.912 .900,00$

$1.849 .144 .381,60$

$39.469 .935 .466,20$
Despesa efetuada \%

$\mathrm{Cr} \$$

1.278.627.281,50 92

$7.484 .332 .639 .00 \quad 110$

$15.059 .002 .186,40 \quad 92$

$2.083 .522 .575,90 \quad 128$

$4.272 .757 .609,40 \quad 75$

$5.717 .981 .371,60 \quad 114$

$628.634 .591,00 \quad 79$

(a)

$36.524 .858 .254,80$

Nota: (a) - O S.A.P.S. ainda não enviou seu balanço ao Tribunal de Contas, e por isso não é conhecida a despesa efetuada.

Com base nos orçamentos para o corrente ano e dos cumpridos no ano que findou, podemos verificar pelo crescimento que a tendência será a seguinte: (Considerado o volume total dos orçamentos).

$$
\begin{aligned}
& 1958 \text { - Cr\$ 39.500 Milhões, aproximadamente; } \\
& 1959 \text { - Cr\$ 67.500 Milhões, aproximadamente, e } \\
& 1960 \text { - Cr\$ 100.000 Milhões, provàvelmente. }
\end{aligned}
$$

Sòmente no que tange às instituições citadas, o vulto orçamentário deverá atingir no próximo exercicio à elevada cifra de Cem Bilhões de cruzeiros, o que sugere medidas especiais. Há, ainda, outros pontos a serem observados. As instituições de previdência realizam operações imobiliárias para auferirem rendas e para servir socialmente a seus segurados. Além disso, elas possuem bens imóveis que representam altos valores e formam seu patrimônio. Vamos dar, abaixo, um quadro onde a primeira coluna representa os valores dos imóveis da instituição e a segunda, os valores de financiamentos, promessas de compra e venda, e hipotecas, pelos saldos devedores:

$\mathrm{Cr} \$$

I. A. P. B. $\ldots \ldots \ldots \ldots$

I. A. P. C. $\ldots \ldots \ldots \ldots$

I. A. P. I. $\ldots \ldots \ldots \ldots$

I. A. P. M. $\ldots \ldots \ldots \ldots$

I. A. P. E. T. C. .....

C. A. P. F. E. S. P. .

Total
2.260.153.286,90

3.755 .528 .823 .50

2.994.716.290,40

$381.920 .418,70$

$1.724 .830 .150,00$

$771.333 .452,60$

11. 888.482 .422 .10
Cr\$

695.311.882,00

2.629.938.340.80

1. $616.553 .926,20$

$225.975 .114,50$

$582.885 .202,60$

1. $457.649 .999,20$

$7.208 .314 .465,30$

Assim, entre imóveis de propriedade das instituições e o montante dos saldos dos diversos empréstimos, temos $\operatorname{Cr} \$ 19.096 .796 .887,40$. 
Não figura no quadro acima e haveria parcela a computar na primeira coluna o que se refere ac S.A.P.S., isto porque, não foi mandado ao Tribunal de Contas seu balanço. Se computado, o montante deveria ultrapassar a casa dos vinte bilhões de cruzeiros.

Temos, agora, em exame outra fonte de ingressos, ou seja o Fundo Ünico da Previdência Social que arrecada a «Quota de Previdência» e representou em 1958 um total de $\operatorname{Cr} \$ 2.470 .594 .850,90$, sendo estimada a arrecadação em 1959 em mais de três bilhões de cruzeiros.

Entremos, agora, no capítulo - Dívidas para com as instituições de Previdência. Primeiramente verifiquemos as da União; ei-las:

$\mathrm{Cr} \$$

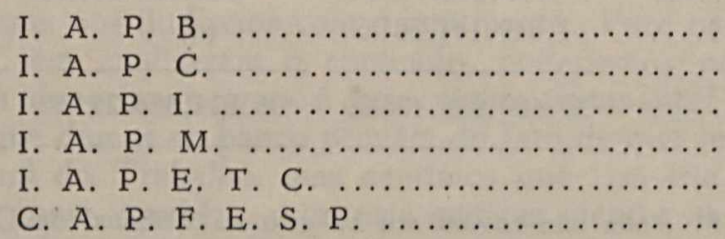

Total
$2.432 .734 .006,50$

$12.385 .366 .669,60$

$33.975 .638 .372,90$

$363.151 .054,80$

$3.852 .079 .087,60$

$5.216 .977 .026,90$

$58.498 .946 .218,30$

Esta é a divida registrada, embora na imprensa se diga que atinge a mais de 80 bilhões ( Correio da Manhã» de 25-7-1959). Por outro lado, o crescimento dessa divida não nos faz acreditar nas estimativas feitas de que em 1960 será acrescida de mais 30 bilhões de cruzeiros, mas deverá ser de, aproximadamente, vinte bilhões.

Em resumo, computando-se os valores orçamentários, os patrimoniais de movimento e outras fontes de ingressos, podemos fazer uma estimativa aproximada do vulto das operações, como segue, abaixo:

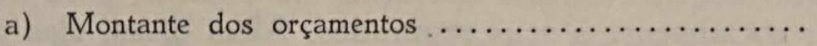

Cr\$

b) Empréstimos e imóveis vendáveis $\ldots \ldots \ldots \ldots \ldots \ldots \ldots$

67 bilhões

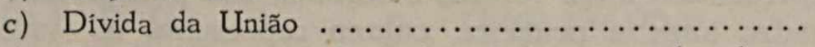

d) Dividas de empregadores, de acôrdo com quadro abaixo

13 bilhões

58 bilhões

21 bilhões

Total

159 bilhões

Êstes elementos são os referidos nos balanços, contas e orçamentos das entidades. Devemos estimar para 1960 um acréscimo, assim decomposto:

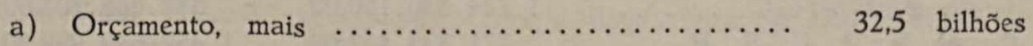

b) Empréstimos, etc., mais .................. 2,5 bilhões

c) Divida da União, mais ................. 20,0 bilhões

d) Dividas de empregadores, novas, mais $\ldots \ldots \ldots \ldots$ bilhões

Soma

60,0 bilhões 
Torna-se indispensável, ainda, prestar certos esclarecimentos que dizem respeito a êste trabalho. O SASSE, nóvel instituição previdenciária, acha-se subordinado ao Ministério da Fazenda, embora por sua natureza devesse estar na órbita do Ministério do Trabalho, pois é um instituto de previdência. Em 1958 arrecadou $\mathrm{Cr} \$ 51.533 .743,40$ e no que tange a valores imobiliários, suas contas atingem a Cr\$ 25.293.852,30. Assim, poderiamos incluir em nossos cálculos mais uma parcela de Cr\$ 76.827.595,70.

A Fundação da Casa Popular, em 1958, previa uma receita de Cr\$ 82.400.000,00 e arrecadou $55.378 .009,10$ e os bens imóveis que figuram em seu balanço atingem a Cr\$ $1 \cdot 442 \cdot 200 \cdot 418,60$. Temos, assim, mais a apreciável parcela de $\operatorname{Cr} \$ 1.497 .578 .427,70$.

Não podemos oferecer dados sôbre.o I.P.A.S.E., Instituto do Mate e do Pinho, porque não enviaram, ainda, suas contas ao Tribunal de Contas. O Instituto de Resseguros não presta contas àquele Tribunal.

Como vemos, as parcelas se adicionaram e nos permitem avaliar o vulto a que êste setor atinge e por isso exige a maior atenção e cuidado pelo seu significado para com a economia nacional.

Dividas dos empregadores. - Essas dividas dos empregadores incluem a parte de sua contribuição, a contribuição do empregado descontada do ordenado pelo empregador e não recolhida ao Instituto (crime de apropriação indébita) e consignações em fôlha não recolhidas, também e criminosamente, além de juros de mora e multas devidas. É curioso notar que a legislação não estabeleça meio para uma ação rápida contra os que, afrontando a lei, deixam de recolher as contribuições, cometem crimes de apropriação indébita e conseguem se manter na impunidade acintosamente e, o que é de lastimar, contando com amparos políticos para tanto.

O quadro abaixo especifica, por entidade, o volume dessas dividas, nao incluindo o I.A.P. dos Comerciários que não faz constar de seus balanços o montante dessas dividas, o que dá que pensar.

$\mathrm{Cr} \$$

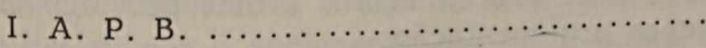

$25.529 .418,20$

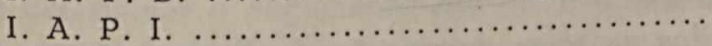

$8.830 .481 .511,80$

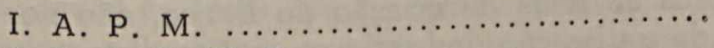

I. A. P. E. T. C.
C. A. P. F. E. S. P. $\ldots \ldots \ldots \ldots \ldots \ldots \ldots \ldots$

$7.175 .043 .524,20$

$189.121 \cdot 162,50$

$5.430 .581 .995,50$

Total

$21.650 .757 .612,20$

Em relação à «quota de previdência» deve ser lembrado que as emprêsas estatais, autárquicas ou de economia mista, que exploram serviços sôbre os quais incide aquela quota, em sua maioria, não a recolhem ao Fundo Único, embora tenham cobrado e recebido o dinheiro, apropriando-se, também, indèbitamente do que não lhes pertence.

Além do que vimos acima, estarão na órbita do Banco outras entidades, como os Institutos de Resseguros do Brasil, do Pinho, do Mate, a Fundação da Casa Popular, a Eqüitativa dos Estados Unidos do Brasil e o Impôsto 
Sindical que deve atingir aproximadamente, em 1960, a Um Bilhão de cruzeiros, sendo que dessa soma só a parcela de vinte por cento se destina ao Fundo Social Sindical e, às entidades sindicais são entregue os outros oitenta por cento.

Assim, adicionadas tôdas as parcelas poderíamos supor que o Banco teria, em 1960, já um movimento de, aproximadamente, 170 bilhões de cruzeiros, importância essa que autoriza indiscutivelmente a criação de um estabelecimento bancário especializado, ao qual deveriam ser deferidos encargos que estão com as instituições, indevidamente.

Apresentado o lado financeiro da questão, mister se faz examinarmos as razões para a criação dêsse banco. O volume de dinheiro a ser movimentado, por si só, aconselha a sua criação, mas há outros fatôres, como iremos apontar.

As entidades previdenciárias são essencialmente securitárias e parcialmente assistenciais, pois são destinadas ao atendimento das aposentadorias e das pensões - não tendo sido previsto nos cálculos atuariais para sua organização, o encargo assistencial. Êste encargo é outro fator de falência da organização, pois a receita não o comporta e quando as taxas dos institutos foram majoradas para atenderem a êsse encargo, por decisão judicial, tiveram de ser reduzidas. É curioso que se queira a prestação de um serviço caro mas se negam os meios para sua perfeita execução.

Sendo essas entidades previdenciárias, a aplicação de suas reservas, de seus fundos é uma necessidade, pois têm de auferir benefícios para, mais tarde, suportar os encargos a que estão obrigadas. Para tanto, criaram essas entidades setores para a aplicação de seus haveres, setores de empréstimos, de hipotecas, imobiliários, de engenharia, de patrimônio, etc. que não se comportam nas suas finalidades mas constituem necessidade no momento verificando-se as maiores disparidades nos serviços, procedimentos, bases e meios, entre as diversas entidades, como não existe um plano geral previdenciário. A falta de unidade é altamente prejudicial, quer ao regime previdenciário, quer aos contribuintes e, pelo vulto, ao próprio interêsse nacional. A unificação, seguida da uniformização de métodos e de procedimentos é uma providência que se impõe naturalmente e dispensa argumentação.

Como estamos limitados ao tema da criação do Banco, não nos é dado falar sôbre a necessidade da unificação dos serviços assistenciais, o que já foi tentado, através do paralizado Serviço de Assistência Médica da Previdência Social (S.A.M.P.S.), aliás um caso de paralisia infantil, já que aos seis meses de idade, foi acometido daquele mal, não mais funcionando, sem ter sido extinto...

A falta de uma unificação dos serviços assistenciais os encarece e concorre para o estado de insolvência hoje notado. Êste problema comporta uma monografia em separado, razão por que não o estudamos neste trabalho.

A legislação vigente impede o depósito, por parte dos órgãos governamentais de qualquer natureza, em bancos particulares, obrigando a que sejam feitos sòmente no Banco do Brasil S.A. Êsse organismo paraestatal não auxilia as entidades previdenciárias, pois é moroso, cobrar percentagens sôbre as remessas feitas, o que bancos particulares não fazem, retém importâncias a tal ponto que os institutos se vêm na contingência de ter caixa alta para 
poderem atender nas épocas próprias seus compromissos. Não raro, sabemos da vinda de servidores a esta Capital para buscar dinheiro, a fim de evitar a remessa através do Banco do Brasil, pois além da demora, haverá o pagamento de taxas tão grandes que se torna mais barata a vinda de um servidor ao Rio de Janeiro, computando-se as passagens, diárias, e outras despesas, embora a instituição corra o risco natural com êsse procedimento. Poderá o estabelecimento oficial negar, mas quem conhece a realidade bem sabe que isto é a pura verdade.

Os critérios do Banco do Brasil são até curiosos. De acôrdo com o disposto no Decreto $\mathrm{n}^{\circ} 40.401$, cabe ao Ministro do Trabalho, Indústria e Comércio, movimentar as contas do Fundo Social Sindical naquele Banco. Pois bem, êsse Ministro, a quem o Decreto conferiu a capacidade, baixou portaria disciplinando a forma de realização de despesas nos Estados e nessa regulamentação, exigia que os encarregados dos setores só efetuassem pagamentos por meio de cheques nominais e mensalmente teriam de prestar suas contas, anexando o extrato da conta na agência do banco. É de ser notado, que, primeiramente o Ministro movimentava no Banco a Conta, mediante cheque e, depois, em vez de entregar em mãos o dinheiro, mandava creditá-lo na agência do banco, como uma medida de defesa dêsse dinheiro. O Banco do Brasil como interpretador das leis, declarou que a Portaria do Ministro era inválida e não abriria contas nas suas agências para serem movimentadas pelos chefes dos setores regionais! Resultado: - O Ministro saca da Matriz a importância e remete nominalmente ao chefe do setor a importância, pagando taxa de remessa, e êste último recebe o dinheiro, não podendo depositá-lo no Banco como chcfe do setor e então, ou fica com êle no bôlso, ou deposita em sua conta particular em banco particular ou Caixa Econômica, auferindo os juros! Isto por que o Banco do Brasil interpreta leis. Haverá quem defenda a justeza do ato do Banco e aceite como boas as conseqüencias?

Por outro lado, sabemos que a arrecadação das instituições se faz em todo o território nacional, mas se uma instituição tem seus recursos depositados no Banco do Brasil, êstes o são na sede, para efeitos de escrituração, e se tiver de determinar o pagamento em outro ponto do território nacional, terá de pagar taxas de transferência, selos, telegrama, etc., embora o dinheiro vá ser entregue pelo Banco no local onde foi arrecadado! Com $1 \mathrm{~m}$ banco da previdência, para servir à previdência, tal não ocorrerá, pois a própria organização determinará a retenção nos locais convenientes, evitando-se as remessas e assim será mais expedito e mais barato o trabalho.

A movimentação dos recursos previdenciários através de uma entidade sua, é muito mais simples e mais fàcilmente controlável, mesmo porque as próprias instituições serão as fiscais dêsse banco. O Banco do Brasil já possui um tão grande acervo de compromissos, são tantas as suas atividades, que não pode ter maior interêsse em atender à previdência social e, por outro lado, estando o Banco do Brasil na órbita do Ministério da Fazenda, conseqüentemente obedece às ordens do titular daquela pasta o qual, por êsse meio, gere a pasta do Trabalho.

Em qualquer organização o caixa da emprêsa cumpre ordens e jamais a dirige, mas no Estado, o caixa, isto é, o Ministério da Fazenda é o supremo 
dirigente, de vêz que tem em suas mãos o Banco do Brasil e a lei obriga a que todos os depósitos de entidades públicas aí sejam feitos. Esta é outra razão para a criação do Banco.

O BANCO. (B.N.P.S.)

Falemos, já agora, sôbre a organização do Banco pois as razões que ditam sua criação já fôram apresentadas.

Capital - Poderá ser de um bilhão de cruzeiros, subscrito pelas entidades previdenciárias. Para isso o Tesouro fornecerá os recursos à conta da divida da União. As ações serão distribuídas pela instituições na proporção de seus créditos na Dívida da União.

Natureza - Autárquia federal, como o Banco Nacional do Desenvolvimento Econômico, gozando de todos os privilégios deferidos à administração pública federal.

Âmbito - Nacional, com sede na Capital da República e agências e filiais nas capitais dos Estados e Territórios e nas cidades onde o movimento o justifique.

Subordinação - Ao Ministério do Trabalho, Indústria e Comércio, já que se destina às operações da Previdência Social e outras atividades da área dêsse Ministério.

Finalidade - Receber os depósitos das entidades previdenciárias, da Eqüitativa, do I.P.A.S.E., de Resseguros do Mate e do Pinho; efetuar o recebimento das contribuições aos institutos e Caixa; movimentar os recursos nêle depositados, atendendo aos pagamentos solicitados pelos depositantes; receber as contribuições da «Quota de Previdência» e atender aos respectivos pagamentos às entidades; manter serviços imobiliários, realizando as operações, inclusive as aplicações das reservas das instituições; praticando as operações bancárias que lhe forem permitidas na lei; incorporar os órgãos imobiliários e patrimoniais das instituições de previdência; cobrar e receber em depósito o Impôsto Sindical e efetuar a distribuição, nos têrmos da legislação vigente e segundo as determinações do Ministro do Trabalho, Indústria e Comércio, e praticar os demais atos que a lei lhe permitir.

Estrutura do Banco - Será dirigido por um Presidente, de livre nomeação pelo Presidente da República, demissivel «ad nutum». Terá um DiretorSuperintendente, com atribuições iguais ao do B.N.D.E., subordinada àquele a Superintendência, à qual serão afetos diversos serviços internos do Banco; terá um Diretor para dirigir cada uma das seguintes carteiras: Imobiliária, Patrimonial, Arrecadação e Cobrança, Hipotecária e de Financiamento, Sindical, Comercial, e de Crédito Geral; haverá um Conselho Fiscal integrado por dez membros, sendo um Presidente, de livre nomeação pelo Presidente da República, três representantes dos empregadores (indústria, comércio e comunicação), três representantes dos empregados (indústria, comércio e comunicações), e três representantes do Estado, sendo um indicado pelo Ministro do Trabalho, Indústria e Comércio, um pelo Ministro da Fazenda, e um pelo 
Conselho Nacional da Economia; haverá uma Junta de Contrôle, com podêres especiais, integrada por um representante do Tribunal de Contas, um da Contadoria Geral da República e um do Ministério do Trabalho. Indústria e Comércio, indicado pelo Serviço Atuarial. Sôbre as atribuições do Conselho Fiscal e da Junta de Contrôle, falaremos adiante.

Funcionalismo - $\mathrm{O}$ quadro será organizado de modo a atender às necessidades do Banco. Dado o reconhecido excesso de pessoal no serviço público, em geral, serão transferidos das diversas entidades e da administração direta os servidores para integrarem o quadro, mediante seleção, extinguindo-se as vagas resultantes do aproveitamento dos servidores, não havendo, assim, aumento de funcionalismo no serviço público. As formas de transferências serão reguladas na lei institucional do Banco, a fim que a nova entidade possa contar com um grupo apto e selecionado para a execução de seus serviços.

Recursos e meios de ação do Banco - Além do Capital, o Banco passará a fazer girar os recursos provenientes dos depósitos de modo a atender às instituições segundo suas necessidades administrativas e previdenciária. O Banco estará permanentemente entrosado com as entidades, a fim de programar o atendimento das necessidades habituais em data certa, não ocorrendo, dessa forma, o retardamento no pagamento de benefícios aos segurados ou seus dependentes.

Divida da União - A União deverá contratar com o Banco a forma de liquidação de sua divida, podendo entregar, como parte de pagamento, imóveis de sua propriedade, como, por exemplo, os localizados na Cidade do Rio de Janeiro, desnecessários a partir da mudança da Capital Federal para Brasília. Além disso, a União poderá, também, transferir para o Banco suas ações na Companhia Siderúrgica Nacional, Companhia Hidrelétrica do Vale do São Francisco, Companhia Vale do Rio Doce, Fábrica Nacional de Motores e outras, para que o Banco, se fôr conveniente, as venda e dêsse modo possa ir sendo resgatada a dívida da União. Por outro lado, a União poderá transferir, também para pagamento, parte de suas ações nos bancos do Brasil e do Desenvolvimento Econômico. De futuro, o Orçamento federal deverá consignar uma rubrica especial para amortização da dívida da União e a parcela correspondente aos encargos desta relativos ao ano anterior, importâncias essas que serão consideradas automàticamente registradas pelo Tribunal de Contas e distribuídas ao Tesouro, cabendo a êste, sob a responsabilidade pessoal do Ministro da Fazenda o pagamento ao Banco Nacional da Previdência Social, até o dia 31 de março de cada ano, importando em crime de responsabilidade a não execução desta medida. A ação neste caso poderá ser iniciada por qualquer representante no Conselho Fiscal ou na Junta de Contrôle, e ao Tribunal de Contas cabe não aprovar as Contas do Presidente da República se não verificar o cumprimento desta medida.

Dividas dos empregadores - As entidades credoras deverão providenciar sua cobrança, inclusive por meio de ações judiciais, se necessário, principal mente nos casos de apropriação indébita. A lei deverá impedir que os devedores transacionem com o Estado, com o Banco do Brasil e Nacional do Desenvolvimento Econômico, assim como, através da SUMOC, deverão ser tomadas 
medidas para que os diversos estabelecimentos bancários sejam impedidos de transigir com os que não apresentem comprovação de estarem quites com as instituições de previdência. Êste é um meio para evitarmos a ruína das instituições securitárias, forçadas por essas e outras causas. Ante o mal, devemos usar remédios eficazes, sem atendermos a interêsses mesquinhos de uns poucos, principalmente quando estão em jôgo os grandes interêsses da coletividade. Os remédios são conforme as doenças.

Aliás êste assunto vem sendo ventilado no Congresso Nacional, na imprensa e nas organizações sindicais, tendo sido apresentados diversos projetos a respeito. É indispensável que providenciemos legislação coercitiva, a fim de por côbro a uma situação inexplicável. Para darmos uma idéia neste particular, basta lembrarmos o ocorrido com o chamado «Grupo Carreteiro» que explorava o serviço de transporte entre as cidades do Rio de Janeiro e Niterói. São devedores de mais de sessenta milhões de cruzeiros só ao Instituto de Aposentadoria e Pensões dos Marítimos e, no entanto, nessa situação recebiam auxílios financeiros do Govêrno Federal! É de ser notado que o auxilio só pode ser entregue se o devedor estiver quites com os cofres públicos, mas havia meios para aquêle «Grupo» recebesse subvenções sem provar sua quitação com o I.A.P.M.... Foi necessária uma ação popular violenta para que a administração pública sentisse a gravidade da situação. Não será necessário falar sôbre o ocorrido, pois os fatos se tornaram públicos pela imprensa e pela divulgação feita pela Interventoria, o fato é que êste caso bem mostra a necessidade de legislação que possa compelir ao pagamento do devido às instituições previdenciárias.

No débito para com a previdência social encontramos o relativo à "quota de previdência" das entidades oficiais, autárquicas, e de economia mista que exploram serviços de utilidade pública, as quais arrecadam aquela quota e não a recolhem ao Fundo Único da Previdência Social. É fato gravíssimo, pois a entidade, no caso, funciona como mera cobradora, é uma depositária por lei e por pequeno período, e, no entanto, apropria-se indèbitamente do que não lhe pertence, gere o dinheiro e não o entrega a quem de direito. Trata-se de crime. Quando um indivíduo se apropria de um pão, sente os rigores da lei, tem de se haver com a polícia e tôda a máquina judicial se movimenta, mas quando se trata de organismos potentes, quando estão em jôgo interêsses politicos, praticam-se crimes impunemente. Que moral terá o Estado para punir os pequenos, os fracos, os desprotegidos se êle dá o exemplo, se é relapso, se pauta suas ações pela ilegalidade?

Atribuições do Conselho Fiscal e da Junta de Contrôle -. O Conselho Fiscal, dada sua forma de constituição, deverá ser um órgão de orientação, conselheiro, executando um contrôle que, por uma ação de acompanhamento dos atos da direção executiva, não deve ser simplesmente fiscal, tomador de contas, apontador de erros ou falhas, deve integrar-se na administração para indicar, no momento preciso, a melhor forma de procedimento. Não se deve constituir em etapa burocrática, em delonga, mas num auxiliar constante e consultivo, já que as atribuições de fiscalização são afetas a outro órgão: Os conselhos fiscais têm sido inexpressivos, complacentes ou intolerantes. Não são essas as atitudes que êle deve assumir; sua função deverá ser antes de tudo, orientadora, assim como deverá ter podêres para sustar qualquer ato, 
caso a direção executiva entenda de o praticar, mesmo depois de advertida dos males que possa causar, assumindo integral responsabilidade pelo seu ato. Em tal hipótese, a direção poderá tomar a atitude que se faça necessária, recorrendo ao Ministro de Estado e, conforme o caso, o dirigente poderá ser responsabilizado ou afastado, ou os próprios membros do Conselho Fiscal, se provada ficar a improcedência de sua acusação ou dos males decorrentes da sustação do ato da direção. É necessário atribuir-se competência ao Conselho Fiscal para agir, responsabilizando-o por seus atos, bem como obrigando-o a opinar, se solicitado, em prazo curto, e se o não fizer, implicitamente revelará incompetência, podendo ser causa para a substituição de seus membros.

A Junta de Contrôle, como proposta, será a fiscal efetiva e tomadora constante de contas e por isso mesmo é integrada por representantes do Tribunal de Contas, da Contadoria Geral da República e do Serviço Atuarial do Ministério do Trabalho, Indústria e Comércio. Sua função será efetivamente de fiscal, de preparadora do julgamento futuro e definitivo pelo Tribunal de Contas, segundo o preceituado na Constituição.

Aos que estão habituados com a forma atual, pode parecer que haja uma duplicação de órgãos, mas tal não ocorre. O Conselho deve ser orientador e a Junta, controladora. Nas sociedades anônimas vemos o Conselho Fiscal com podêres de contrôle e obrigado a emitir parecer sôbre as contas para ser apreciado pela Assembléia-Geral, mas aí se trata de organização particular e os acionistas têm competência para escolher aquêles que devem fiscalizar. Já em relação aos órgãos públicos, a atitude deve ser outra. Entretanto, mesmo nas emprêsas privadas, não raro, vemos o Conselho Fiscal se valer do exame que manda executar na escrita, por peritos. Porque? Questão de competência, de conhecimento. Assim, a fiscalização contábil a parte que interessa ao Tribunal de Contas e às contas públicas, deve ficar afeta à Junta de Contrôle, capacitada para isso, mas ao Conselho Fiscal deve ser reservada tarefa de outra natureza, isto é, no que concerne aos fatos administrativos, à orientação geral, aos destinos do empreendimento, não se tratando de contrôle contábil.

Para melhor elucidarmos nosso ponto de vista, formularemos uma hipótese. Suponhamos que uma operação de financiamento vá ser feita. Sua conveniência, oportunidade e volume, devem ser objeto de apreciação pelo órgão orientador. Se a ação fôsse apenas do tipo de contrôle contábil ou mesmo legal, essa operação, guardando conformidade com a lei, respeitando as regras e normas vigentes, não poderia ser recusada por um órgão simplesmente fiscal. Entretanto, a um orientador e conselheiro, poderá evidenciar-se inconveniente e recusável. Pela distinção de atribuições, compreendemos a necessidade dos dois órgãos, maximé em se tratando de um organismo do vulto que sugerimos seja criado. O enfeixamento de atribuições nas mãos de um simples Conselho Fiscal, dar-lhe-á fôrça política e capacidade para influir nefastamente na direção, justificando-se, assim, a existência de dois órgãos distintos, o que dará maior perfeição ao contrôle e facilitará a administração, inclusive evitando intromissões prejudiciais à mesma.

Funcionalismo do Banco - Quando é ventilada a criação de um novo organismo, imediatamente surge o problema do "empreguismo". Linhas acima, já demos rápida notícia sôbre o modo de provimento dos cargos no Ban- 
co; mister se faz lembrar que, pela natureza ou qualidade das funções, poderá inexistir pessoal habilitado no serviço público ou que não queira ingres sar no Banco. Nêsse caso, o provimento obedecerá a formas de seleção, como, de futuro, deverão ingressar novos elementos, também, mediante formas seletivas. $E^{\prime}$ necessário que fique bem claro na lei que não poderão ser admitidos funcionários interinos em cargos de carreira, já que essa forma é flagrantemente inconstitucional, embora prevista até na Lei . $^{\circ} 1.711$, de 28 de outubro de 1952 (Estatuto dos Funcionários). O interino é o protegido, o afilhado e não prova competência ou capacidade para ingressar no serviço público, o que constitui um terrivel mal e uma negação do sistema do mérito, além de se revestir de condição antidemocrática pois que não assegura a todos igualdade de tratamento e de oportunidade. Não estamos defendendo tese nova, apenas chamando a atenção para uma situação que já deveria ter merecido de parte dos podêres competentes o necessário exame, mas as fôrças políticas impedem uma ação moralizadora e respeitadora da lei fundamental. Para comprovarmos nossa assertiva sôbre a inconstitucionalidade do provimento dos cargos públicos na condição de interino, tránscrevemos o disposto na Constituição, eis:

"Art. 184. Os cargos públicos são acessíveis a todos os brasileiros, observados os requisitos que a lei estabelecer.

Art. 186. A primeira investidura em cargo de carreira e em outros que a lei determinar efetuar-se-á mediante concurso, precedendo inspeção de saúde.»

A Constituição é taxativa, não abre exceção, e diz que a primeira investidura em cargo de carreira efetuar-se-á mediante concurso, assim pois, sem esta formalidade, o provimento do cargo é inconstitucional, já que o interino não é aprovado prèviamente em concurso para o ingresso no serviço público. $\mathrm{O}$ que hoje verificamos é surpreendente; além do Estado violar a Constituição constantemente, ainda pratica outros delitosinhos... O artigo 186 exige o exame de saúde antes do provimento do cargo, entretanto os interinos são admitidos sem esta formalidade - "porque não houve o concurso e só são obrigados ao exame de saúde os provindos de concurso!..." Como resultado, verificamos o ingresso de enfermos, portadores de moléstias especificadas no Estatuto dos Funcionários, (art. 178, n. ${ }^{\circ}$ III), que asseguram aposentadoria integral, e, pouco tempo após do provimento do cargo, vêm as licenças e a aposentadoria com todos os direitos.

O êrro da violação constitucional ainda resulta em sangria para os cofres públicos e nada acontece aos administradores pois a administração pública vive a mercê das influências politicas, daqueles que fazem do erário público seara própria.

Chamamos a atenção para êste ponto porque na própria previdência social há instituições onde encontramos interinos em cargos de carreira há mais de cinco anos e, depois de marcado concurso no último momento, o mesmo é suspenso porque as fôrças políticas assim o exigem. Não raro há a apresentação de projetos visando efetivar interinos em cargos de carreira, embora inconstitucionalmente, mas o protecionismo continua atuante. 
$\mathrm{Na}$ criação do Banco deve ser tomada precaução para evitar os males do nepotismo, para que haja respeito à Constituição a par de exigências sôbre o exame da vida pregressa do pessoal, sua formação moral, suas idéias e tendências, a exemplo do que é feito nos países democráticos, como a Inglaterra, os Estados Unidos, a França, etc., a fim de evitar que se forme nesse banco um núcleo adverso aos interêsses nacionais, dada a projeção natural que êsse organismo terá.

Como uma primeira idéia da estrutura do Banco, apresentamos, em anexo, o provável organograma. Neste trabalho não há espaço para apresentarmos os projetos de lei, de regime e de regulamento, dada a limitação do número de páginas impôsto, mas já tivemos ocasião de mencionar a semelhança, até certo ponto, com o Banco Nacional do Desenvolvimento Econômico, salvo, certamente, as peculiaridades desta organização que irão estabelecer profunda diferença com aquela outra autárquia bancária.

No organograma anexo vemos a indicação das Agências nos Estados da União, assim como um órgão indispensável que é o Contencioso, onde a contabilidade do Banco $e$ as operações aí realizadas serão anotadas e analisadas.

Quanto às formas a serem adotadas para o funcionamento do órgão, nada de especial se apresenta, pois há paradigmas e podem ser feitas as adaptações. Convém notar que o Banco terá serviços especializados para investimentos, financiamentos, hipotecas, empréstimos, de obras e engenharia, já que lhe competirá fazer as aplicações de capital e de reservas das instituições, além de ser o encarregado da arrecadação e cobrança da receita das instituições, como também de efetuar os pagamentos que lhe forem determinados. Não se compreendem os pagamentos de benefícios, tais como as aposentadorias, as pensões e ajudas de várias espécies, pois essa parte deverá continuar a cargo das instituições.

No que tange às operações do Instituto de Resseguros do Brasil, Institutos do Mate e do Pinho, da Fundação da Casa Popular, da Comissão do Impôsto Sindical, da Comissão Federal de Abastecimento e Preços, do Serviço de Alimentação da Previdência Social e da Eqüitativa dos Estados Unidos do Brasil, êsse órgão funcionará como instituição bancária normal, pequena exceção feita em relação à Fundação da Casa Popular, pois o Banco estará habilitado, por seus setores de engenharia e patrimonial, a executar os serviços dessa Fundação.

Quanto à parte jurídica disporá o Banco em seu Contencioso, além dos setores contábeis, atuariais, de economia e de auditoria, um corpo jurídico, já que terá de enfrentar constantemente questões judiciais. Seu corpo jurídico deverá ser bem selecionado e na área autárquica são encontrados elementos de valor que poderão ser aproveitados. Surgirá naturalmente a questão dos procuradores. A lei $\mathrm{n}^{\circ} 2.123$ estabelecia a equiparação dos advogados e assistentes jurídicos aos procuradores da República, mas sòmente àqueles que já eram à data da lei; quem ingressa num quadro novo não poderá ser beneficiado por uma lei de exceção, que terá visado uma situação até certa data; seus efeitos não se aplicam aos futuros casos. Assim, o Banco poderá ter advogados em seu corpo jurídico, mas a lei deverá ser suficientemente clara para evitar que os novos, como primeiro trabalho no cargo, seja o 


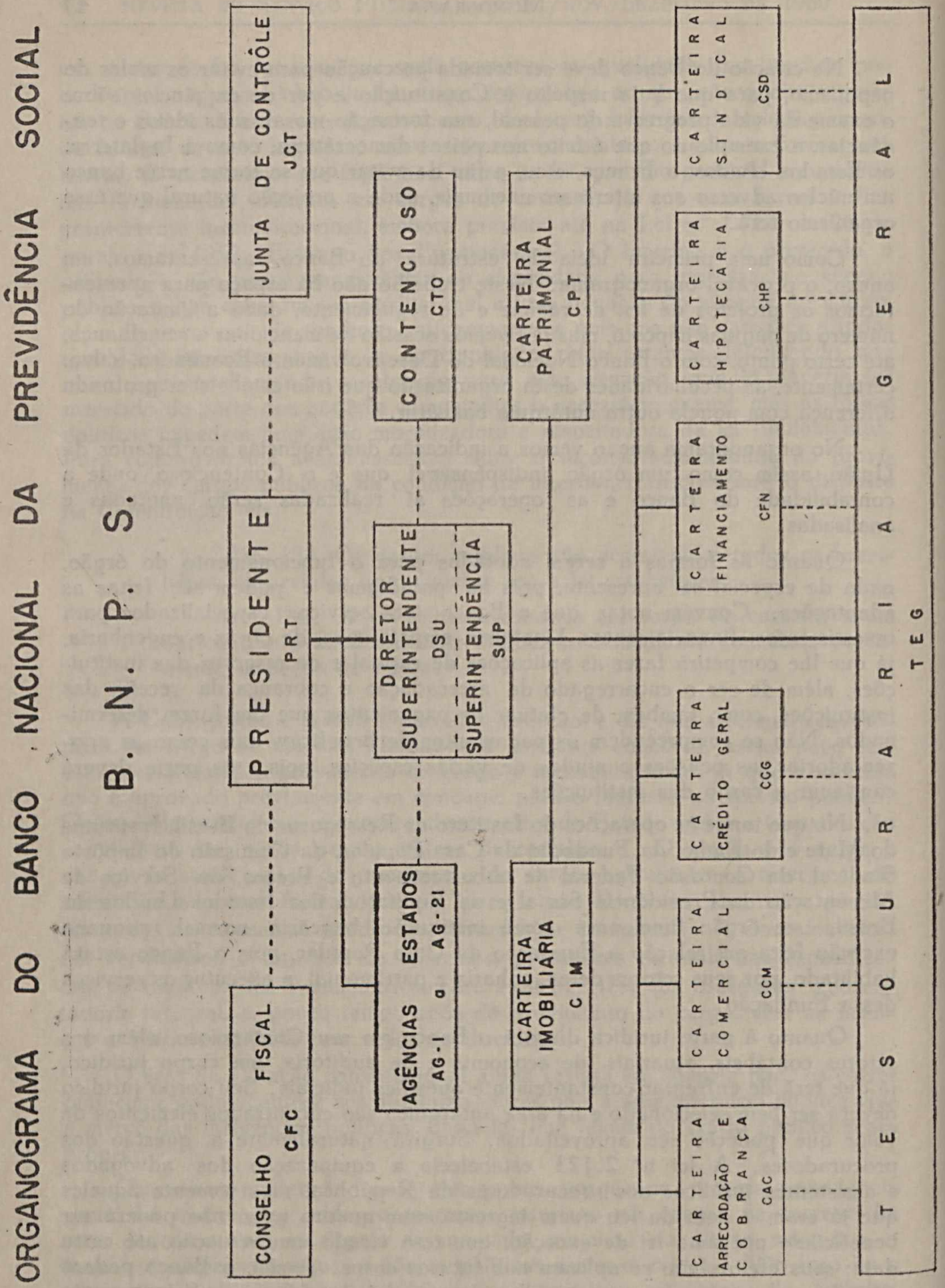


ingresso em juizo para pleitearem contra o Banco e obterem sua equiparação aos procuradores. Deverá ficar consignada a condição de que os novos cargos não serão equiparáveis aos de procurador. Infelizmente hoje temos de tomar precauções, a cada instante, porque existe uma vontade generalizada do aumento de ganhos a qualquer título, merecida ou imerecidamente.

Cremos haver exposto o problema e mostrado a necessidade do órgão; os detalhes constarão de lei, regimento e regulamento.

\section{CONCLUSÃO}

Embora tècnicamente esteja o sistema previdenciário falido, ainda é tempo de serem tomadas medidas para evitarmos sua ruina total, de consequiências inconcebiveis. Tal é a gravidade do assunto que poderemos antever uma revolução social, incontrolável, se não fôr evitada a falência e a paralisação do sistema. Prosseguir no caminho que vem trilhando o Estado será, a nosso ver, o melhor meio para levar o Brasil à revolução social, a qual será aproveitada certamente pelos inimigos da Pátria. Quanto mais fôr feito pelo enfraquecimento do sistema previdenciário mais ràpidamente será nosso povo entregue nas mãos dos dirigentes de ideologias nefastas. É através do rebaixamento moral, das falcatruas, da entrega de instituições a indivíduos de baixa categoria, incapazes, inescrupulosos, como do malbarateamento dos dinheiros públicos e da politização administrativa que melhor se abre o caminho ao domínio de um povo por um grupo ávido de mando e atuante, que só almeja sua escravização, como temos diversos elementos de prova, na atualidade. Se somos patriotas, se desejamos realmente o bem de nosso povo, é mister trabalharmos para a salvação de nossas instituições.

Pelos cálculos aproximados que fizemos, se pudesse êsse Banco já funcionar em 1960, iria girar uma soma superior a 200 (duzentos) bilhões de cruzeiros, quase duas vezes o Orçamento Federal. O vulto bem mostra a necessidade de encararmos com seriedade o assunto, pois êsses valores são geridos e de que forma? Há muito dinheiro confiado a mãos que nem sempre serão as mais limpas e a falta de orientação, a falta de método, de uniformidade, como o descontrôle permitem um desregramento e o malbarateamento dos dinheiros públicos. Poderemos ficar impassiveis ante tal estado de coisas?

Estamos certos de que será afirmado que êsse Banco constituir-se-á numa potência e sua fôrça politica poderá ser prejudicial. Isso será, apenas, argumento daqueles que não desejam a correção de erros e mais se interessam pela subversão do regime, mas improcede. De fato, êsse Banco será uma potência, mas existe o Banco do Brasil e alguém proporia sua extinção por aquêle motivo? Ademais, o Banco situar-se-ia como uma entidade séria e o próprio Banco do Brasil veria enfraquecida sua atual posição de domínio. Certamente o Ministério da Fazenda não iria ver com bons olhos o novo Banco, porque perderia a arma política que possui, isto é, o dinheiro; deixaria de administrar, pelo menos o Ministério do Trabalho e as entidades de sua órbita, como hoje soe acontecer. Para um equilibrio na administração pública seria melhor que o Ministério da Fazenda não possuisse tanta fôrça a qual resulta do dinheiro público que maneja. Qual o Ministério que possui funcionários e em enorme quantidade, ganhando mensalmente quantias que ultrapas- 
sam a casa dos 50 (cinqüenta) mil cruzeiros, indo até a 400 (quatrocentos) mil cruzeiros? Só na Fazenda e daí uma das razões de sua fôrça. Fiscais de Consumo, de Renda, pessoal das Alfândegas, etc. estabelecem um desnivel comprometedor para o equilíbrio social. Assim, se há meios para diminuir o desiquilibrio, é preciso tentá-lo, em benefício da coletividade e da própria segurança das instituições.

A questão previdenciária é, apenas, securatória e assim deve ser tratada. Os intitutos devem ser limitados às suas finalidades, ou seja, aposentadoria e pensões. Já quanto à parte assistencial, é necessário reexame da matéria por não se comportar nos cálculos atuariais para a instituição do sistema. Chegou o momento de serem tomadas as medidas acauteladoras dêsse sistema, evitando-se que sua «debacle» ofereça as condições para a subversão do regime.

O seguro social não pode ser tratado senão em consonância com as regras de enconomia, com os ensinamentos técnicos e por isso, é necessário evitar-se que a lei posterior aumente encargos sem a indispensável cobertura, sendo esta plenamente examinada do ponto de vista atuarial. Os desejam a revolução social têm em suas mãos um meio fácil para que aquela ocorra ràpidamente, isto é, através da paralização da previdência. Como conseguir? Basta realizar campanhas supostamente humanitárias, baseadas no aumento do custo da vida, e visando à duplicação dos valores dos atuais benefícios concedidos. Muito poderá ser alegado em favor de tais campanhas, inclusive o que diz respeito às modificações do valor aquisitivo da moeda, e, por outro lado, bater-se-ão contra o aumento de contribuições. Assim, de um lado aumentam a despesa e de outro impedem a melhoria da receita, dando em resultado o que desejam, ou a total falência das instituições, com a suspensão dos benefícios, o que criaria o clima propício aos fins colimados. Será possivel verificarmos que isto já vem sendo feito cuidadosamente e continuarmos de braços cruzados? O organismo social está minado por moléstia grave, mas como sua fisionomia ainda não apresenta manifestações, fingimos ignorar a realidade. O câncer é uma moléstia que pode ser usada para exemplificar. De início, segundo dizem os médicos, é curável; entretanto, êle leva muito tempo minando o organismo para, no momento final, aparecer e quando isto acontece já é tarde. Estamos como o indivíduo canceroso que já nota sinais, mas tem mêdo de pensar na moléstia e espera o milagre, em vêz de recorrer ao médico para se tratar enquanto é tempo. Livremô-nos do câncer social, antes que seja tarde; tomemos as medidas que se façam necessárias e com urgência, se não desejamos legar a nossos filhos uma Pátria empobrecida, apodrecida, subvertida em seus fundamentos e dominada por algozes.

Não queremos ser pessimistas nem desejamos pintar o quadro com tintas negras e vermelhas, mas sentimô-nos obrigados a revelar nossas impressões e fazer esta advertência, quando o mêdo impede a muitos de se manifestarem claramente. Será necessário trabalharmos e muito para salvarmos o patrimônio que recebemos de nossos maiores, assim como para deixarmos condições de vida aproximadas das que temos tido.

Estamos tão convencidos das realidades a que nos referimos que poderíamos lançar um repto aos que são contrários a nossa idéias para que apresentem provas e argumentos convincentes contra nossas observações, propo- 
sições ou conclusões. Não há de nossa parte o desejo de debate, mas o de alerta, o de contribuir para a melhoria de nossas condições de vida. Antevemos um futuro sombrio em face da trilha que vimos seguido e por isso apresentamos êste trabalho que mais significa um brado de alerta que a revelação de conhecimentos a serem exibidos num concurso de monografias.

Julgando havermos cumprido nosso dever, submetemos êste trabalho aos de espírito bem formado, aos que almejam uma vida melhor para nosso povo, aos que tenham uma consciência cristã e a coragem de enfrentar um problema que deve ser resolvido, a despeito do mêdo de lutar contra situações difíceis, embora o comodismo e outras atitudes sejam as dominantes dos tristes dias que vivemos.

Deixamos, muito propositadamente, de incluir citações de autores, a fim de evitarmos o alongamento dêste trabalho e mesmo porque a idéia que defendemos é comprovada pelos dados que colhemos.

Não podemos, todavia, deixar de revelar que, no momento, a Câmara dos Deputados está procedendo ao estudo para o julgamento das contas do Presidente da República e a imprensa vem noticiando as apreciações feitas. A rigor, poderiamos transcrevê-las, na integra, pois o que ali se contém, justifica nossas observações e nossas preocupações. Assim, o leitor que se interessar pelo assunto, poderá inteirar-se do que, no momento, contitui pensamento dominante na Câmara.

Possuidos de uma fé sincera de que haja a coragem bastante para ser resolvida a questão social dentro dos ideais de humanidade e cristãos que têm sido o apanágio do nosso povo, acordes com a formação que herdamos, finalizamos êste trabalho com certa satisfação pelo dever cumprido. 